\title{
Communication \\ Stress Concentration of Endodontically Treated Molars Restored with Transfixed Glass Fiber Post: 3D-Finite Element Analysis
}

\author{
Alexandre Luiz Souto Borges ${ }^{1}\left(\right.$, , Manassés Tercio Vieira Grangeiro ${ }^{1}$, Guilherme Schmitt de Andrade ${ }^{1}($, \\ Renata Marques de Melo ${ }^{1}$, Kusai Baroudi ${ }^{2}$, Laís Regiane Silva-Concilio ${ }^{2}$ and João Paulo Mendes Tribst ${ }^{2, *(1)}$ \\ 1 Department of Dental Materials and Prosthodontics, Institute of Science and Technology, São Paulo State \\ University (Unesp), São José dos Campos, São Paulo 12245-000, Brazil; alexandre.borges@unesp.br (A.L.S.B.); \\ manasses.grangeiro@unesp.br (M.T.V.G.); guisdandrade@hotmail.com (G.S.d.A.); \\ renata.marinho@unesp.br (R.M.d.M.) \\ 2 Graduate Program in Dentistry, Department of Dentistry, University of Taubaté (UNITAU), \\ Taubaté 12020-270, Brazil; d_kusai@yahoo.co.uk (K.B.); regiane1@yahoo.com (L.R.S.-C.) \\ * Correspondence: joao.tribst@gmail.com
}

\section{check for} updates

Citation: Borges, A.L.S.;

Grangeiro, M.T.V.; de Andrade, G.S.;

de Melo, R.M.; Baroudi, K.;

Silva-Concilio, L.R.; Tribst, J.P.M.

Stress Concentration of

Endodontically Treated Molars Restored with Transfixed Glass Fiber Post: 3D-Finite Element Analysis.

Materials 2021, 14, 4249.

https://doi.org/10.3390/ma14154249

Academic Editor: Deog-Gyu Seo

Received: 10 June 2021

Accepted: 2 July 2021

Published: 29 July 2021

Publisher's Note: MDPI stays neutral with regard to jurisdictional claims in published maps and institutional affiliations.

Copyright: (c) 2021 by the authors. Licensee MDPI, Basel, Switzerland. This article is an open access article distributed under the terms and conditions of the Creative Commons Attribution (CC BY) license (https:// creativecommons.org/licenses/by/ $4.0 /)$.

\begin{abstract}
The loss of dental structure caused by endodontic treatment is responsible for a decrease in tooth resistance, which increases susceptibility to fracture. Therefore, it is important that minimally invasive treatments be performed to preserve the dental structure and increase the resistance to fracture of endodontically treated posterior teeth. To evaluate under axial loads, using the finite element method, the stress distribution in endodontically treated molars restored with both transfixed or vertical glass fiber posts (GFP) and resin composite. An endodontically treated molar 3D-model was analyzed using finite element analyses under four different conditions, class II resin composite (G1, control model), vertical glass fiber post (G2), transfixed glass fiber posts (G3) and vertical and transfixed glass fiber posts (G4). Ideal contacts were considered between restoration/resin composite and resin composite/tooth. An axial load (300 N) was applied to the occlusal surface. The resulting tensile stresses were calculated for the enamel and dentin tissue from five different viewports (occlusal, buccal, palatal, mesial and distal views). According to the stress maps, similar stress trends were observed, regardless of the glass fiber post treatment. In addition, for the G1 model (without GFP), a high-stress magnitude can be noticed in the proximal faces of enamel (7.7 to $14 \mathrm{MPa}$ ) and dentin (2.1 to 3.3 MPa) tissue. The use of transfixed glass fiber post is not indicated to reduce the stresses, under axial loads, in both enamel and dentin tissue in endodontically treated molar with a class II cavity.
\end{abstract}

Keywords: dental restoration failure; endodontically treated teeth; finite element analysis; dental materials

\section{Introduction}

The loss of dental structure caused by endodontic treatment is responsible for a decrease in tooth resistance, which increases susceptibility to fracture [1]. The longevity of endodontically treated teeth is influenced by several factors, such as, the preservation of remaining dental tissue, effectiveness of restorative procedures and occlusal force [2]. Therefore, it is extremely important that minimally invasive dental treatments be performed to preserve the dental structure and obtain success. Additionally, the literature reports that different types of restoration parameters can increase the resistance to fracture of endodontically treated posterior teeth [3].

One of the most common post-endodontic treatments is glass fiber post (GFP) associated with adhesively bonded resin composite restoration in order to increase fracture resistance and reduce the interfacial gap between dental tissues and restorative materi- 
als $[4,5]$. Some authors justify their use because GFP can distribute chewing stresses and occlusal loads on the restoration [6].

In addition, the elastic modulus of post and the direct restorative material must be compatible with the root dentin to reduce the possibility of fracture [7], as well as the root stress magnitude during chewing loads. Aiming to improve the beneficial effects of GFP usage in weakened teeth, several studies have investigated how different clinical parameters can modify the mechanical response during loading, such as GFP geometries, relining, position, and length. Furthermore, previous in vitro studies reported that inserting transfixed GFP could be a viable alternative procedure to reinforce the coronal dental structure, replacing metallic or ceramic posts $[8,9]$. According to a clinical study, this procedure is also economically viable and preserves the natural tooth structure compared to full crown preparation [10].

In this sense, several studies aimed to evaluate the restorative techniques that could reinforce the remaining dental structure, to reduce the stress concentration in the dental structure [11,12] and the probability of fracture through alternative restorative procedures [13]. One of these proposed techniques is the use of transfixed GFP in the tooth crown, and is reported as a contemporary conservative treatment [10]. According to the literature, this restorative treatment has satisfactory aesthetics and easy execution compared to full-crown preparations [14]. However, the mechanical effect of transfixed post placement has not yet been extensively investigated in the literature. In vitro studies are controversial about the mechanical improvements in the fracture load when transfixed glass fiber posts were used to restore posterior teeth $[8,9,15]$. However, no study has evaluated how the transfixed GFP placement can modify the tooth biomechanical behavior and how the stress can be reduced during compressive loading. Therefore, the aim of the present study was to evaluate the stress distribution in endodontically treated molars restored with both transfixed or vertical glass fiber posts and resin composite under axial loads using 3D finite element analysis (3D-FEA). The use of 3D-FEA is the most widely used numerical method, allowing the reproduction of mechanical behavior under a mechanical load based on the properties of the materials [16-21].

\section{Materials and Methods}

\subsection{Modelling}

Finite Element Analysis (FEA) was used to evaluate the mechanical behavior and stress distribution in mesio-occluso-distal class II direct resin composite restoration of maxillary first molar, restored endodontically, and treated with four post-endodontic restorative treatments, including a no-post approach (G1, no-post approach), glass fiber cemented in the palatal root canal (G2), two transfixed glass fiber posts (G3), two transfixed glass fiber posts, and one glass fiber post in the palatal root canal (G4) (Figure 1).

The three-dimensional models were designed in NURBS (non-uniform rational basis spline) CAD (computer-aided design) software (Rhinoceros 6.0SR8, McNell North America, Seattle, WA, USA). An intact first upper molar tooth model (previously reported [16], consisting of enamel layer, dentin layer, root, and pulp chamber) was used to generate the evaluated models. Endodontic treatment was designed using the crown-down technique with $4 \%$ conicity and $25 \%$ tapering. A large class II mesio-occluso-distal (MOD) cavity was performed with $2 \pm 0.5 \mathrm{~mm}$ thickness of remaining wall, $6 \mathrm{~mm}$ isthmus preparation, and gingival wall of $1.5 \mathrm{~mm}$ from the cementoenamel junction (Figure 2). An acrylic resin cylinder was designed to simulate the fixation support, in which the models were positioned, exposing $2 \mathrm{~mm}$ below the restoration margin. The resulting model was used to simulate the evaluated treatments. 


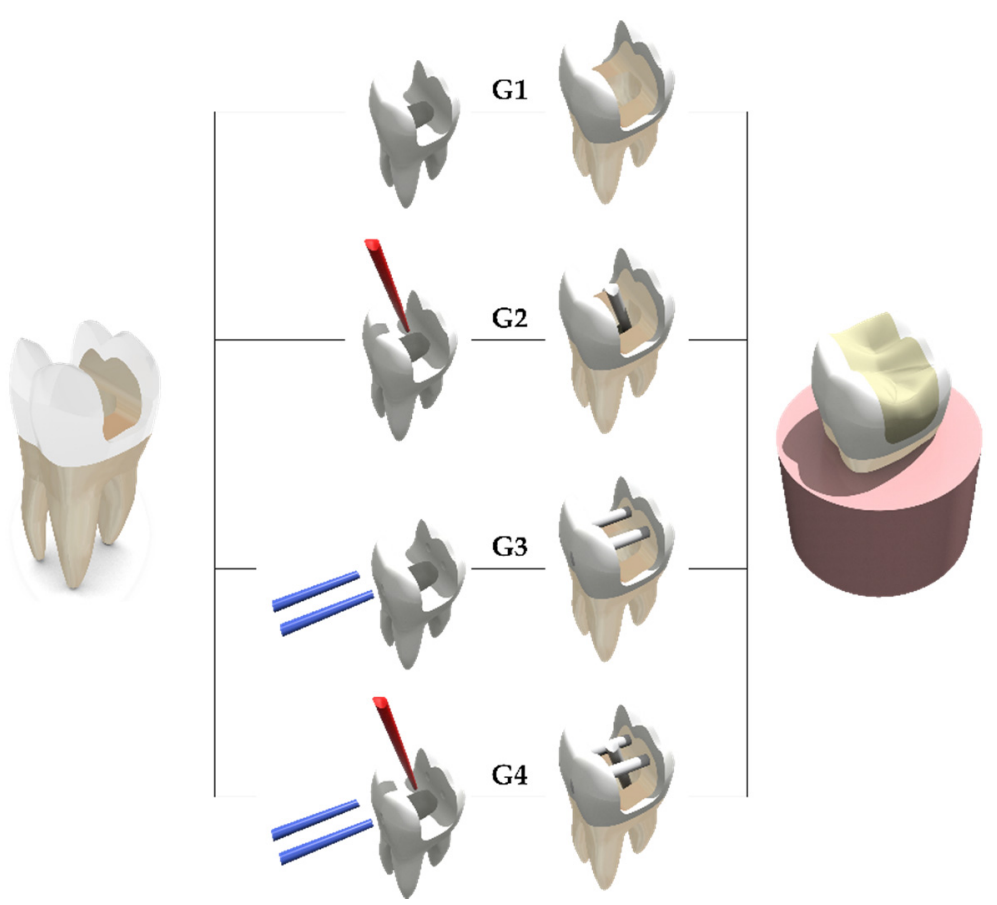

Figure 1. Three-dimensional models created in the modeling software with different post-endodontic restorative treatments: (G1) no-post approach; (G2) glass fiber cemented in the palatal root canal; (G3) two transfixed glass fiber posts; and (G4) two transfixed glass fiber posts and one glass fiber post in the palatal root canal. In red the conventional glass fiber post and in blue the transfixed glass fiber posts.

\section{A}
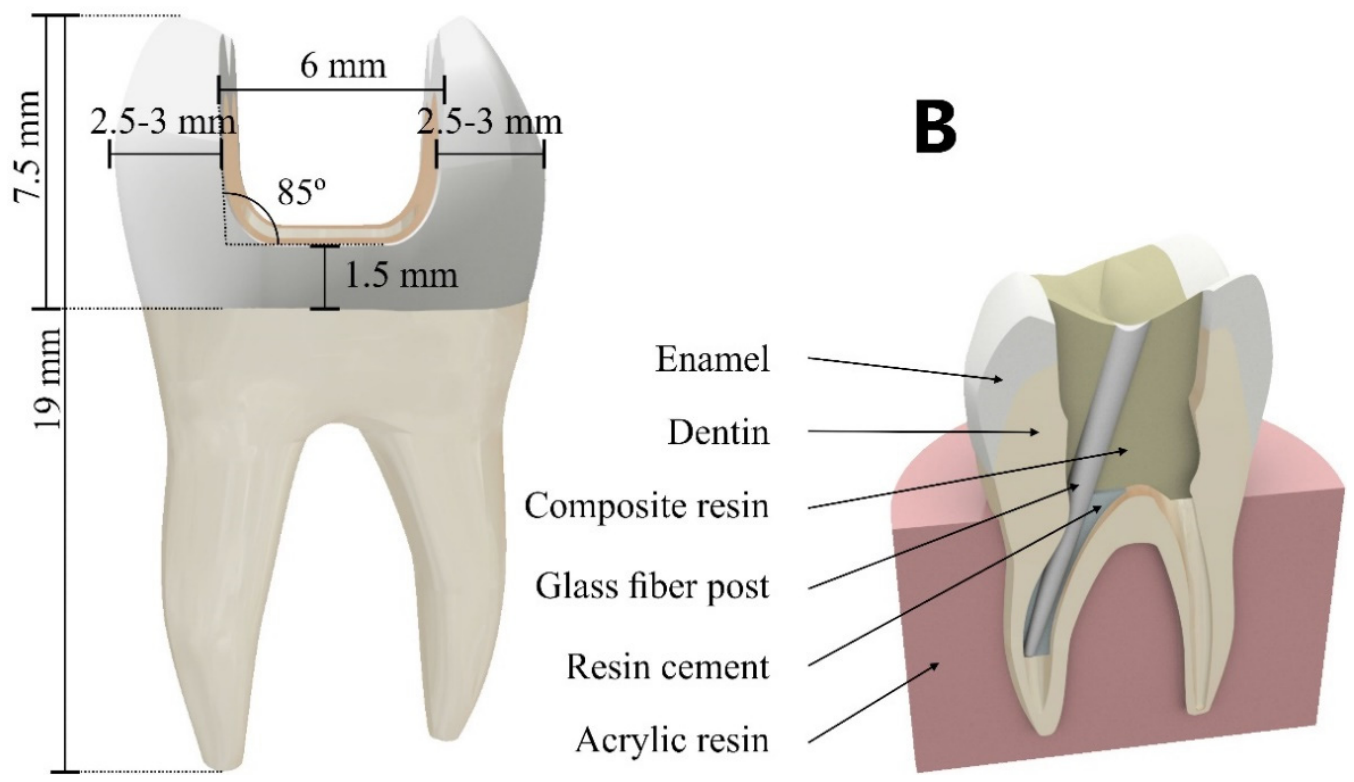

Figure 2. CAD modeling. (A) Class II cavity design; (B) model components.

\subsection{Pre-Processing}

The models were imported to a computer-aided engineering (CAE) software program (ANSYS 19.2, ANSYS Inc., Houston, TX, USA) as a standard for the exchange of product model data (STP) file. Structural mechanical analysis was applied to each group and all 
materials were considered homogeneous, elastic, and isotropic, except for the glass fiber post, which was considered orthotropic. The interfaces in all models were considered perfectly bonded. Table 1 [20,22-29] summarizes the mechanical properties (elastic modulus and Poisson ratio) used for the mechanical analysis. An average of 156,252 nodes and 128,242 tetrahedral, ten nodes, elements were used for the meshing process after a convergence test with a $10 \%$ degree of freedom of the converged value and mesh size, based on the maximum principal stress (MPS) results. During the boundary conditions, the models were fixed (3-axis) on the bottom surface of a cylinder and loaded with $300 \mathrm{~N}$ $\left(90^{\circ}\right)$ distributed in tripod contact area at the central fossa (Figure 3).
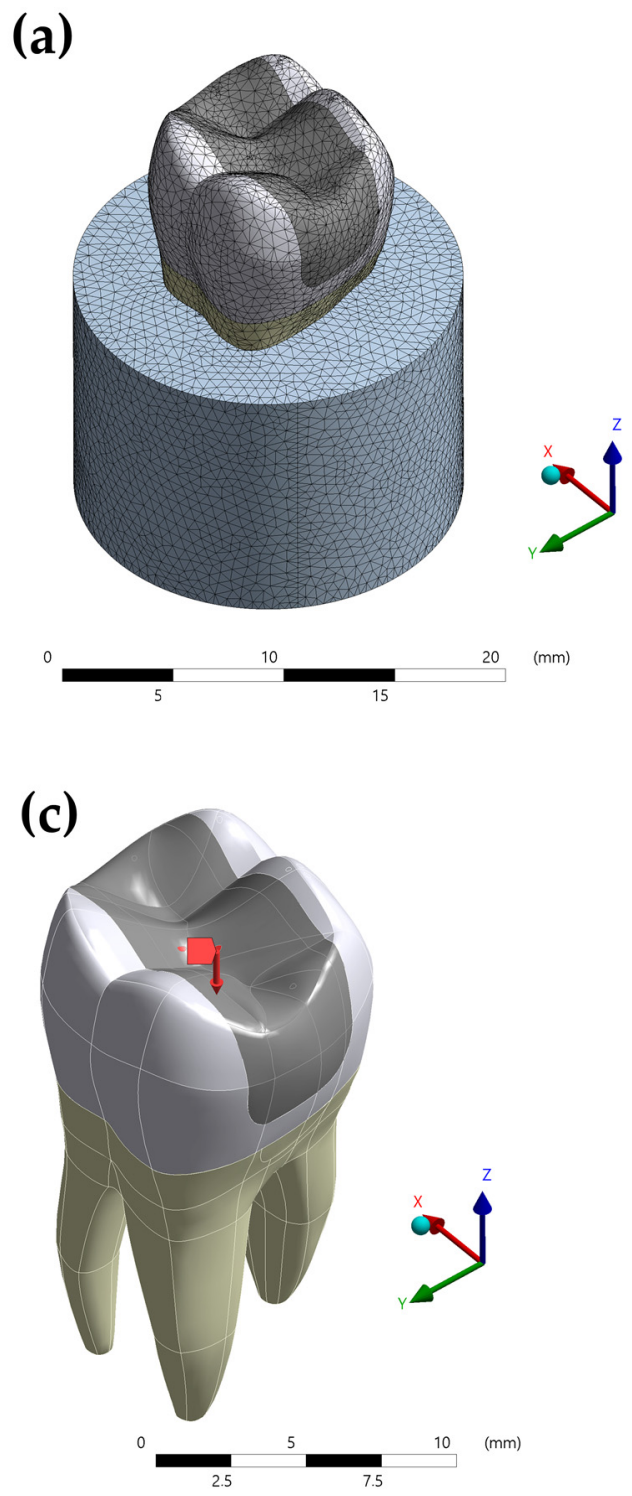

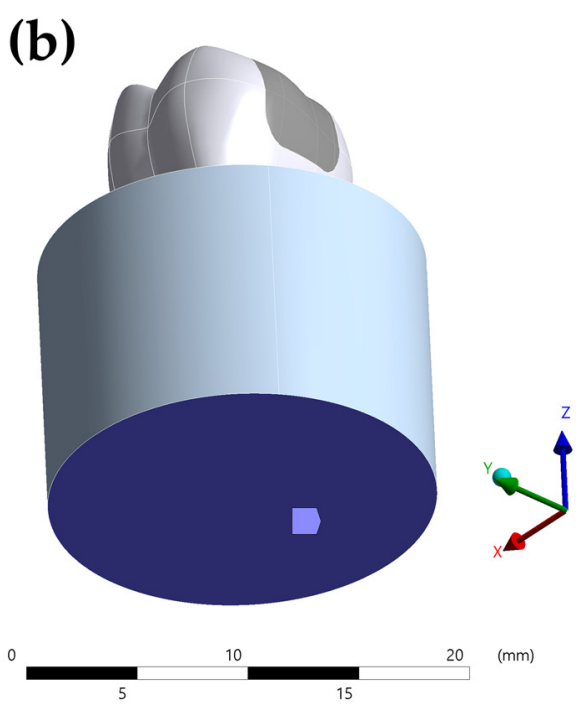

(d)

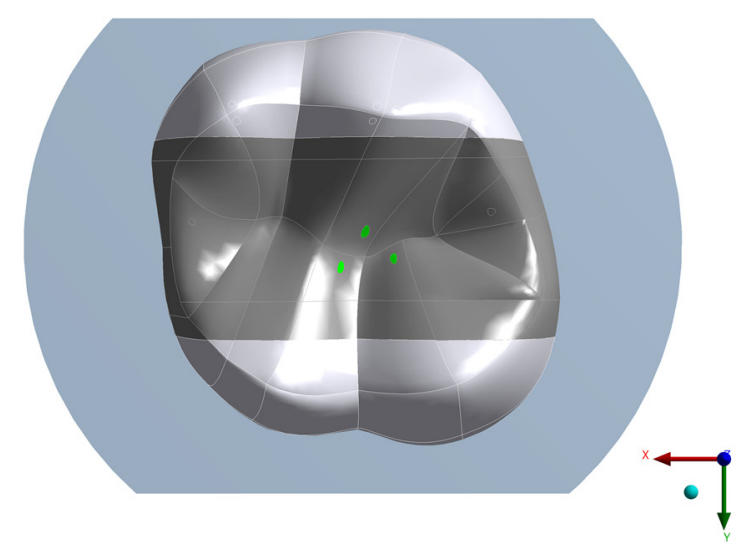

Figure 3. Boundary condition in the present simulation. (a) Mesh generation; (b) fixation of the system; (c) loading settings; (d) tripod contact area. 
Table 1. Stress peaks (MPa) obtained in enamel and dentin tissue after the analysis process.

\begin{tabular}{ccccc}
\hline Material & Elastic Modulus (GPa) & Shear Modulus (GPa) & Poisson Ratio & Tensile Strength (MPa) \\
\hline enamel & $84[23]$ & - & $0.3[23]$ & $15.1-34.3[28]$ \\
dentin & $18.6[24]$ & - & $0.3[24]$ & $44.4-97.8[29]$ \\
resin composite & $8.0[25]$ & - & $0.25[25]$ & - \\
glass fiber post & $\mathrm{x}=37[26]$ & $\mathrm{xy}=3.1[20]$ & $\mathrm{xy}=0.27[26]$ & $\mathrm{xz}=0.34[26]$ \\
resin cement & $\mathrm{y}=9.5[26]$ & $\mathrm{xz}=3.5[20]$ & $\mathrm{yz}=0.27[26]$ & - \\
acrylic resin & $7[25]$ & $\mathrm{yz}=3.1[20]$ & - & $0.24[25]$ \\
\hline
\end{tabular}

The stress distribution in enamel and dentin was recorded as colorimetric maps with adjustable color scales corresponding to the stress magnitude comparison among the preparation designs for each analyzed structure.

\section{Results}

After the processing of first principal stress (tensile), the results were calculated for the models in each of the tooth faces (occlusal, buccal, mesial, palatal and distal). The tensile (Figures 4 and 5) and von-Mises (Figures 6 and 7) stress data were summarized using stress maps for the enamel tissue and dentin tissue. According to the qualitative results, a similar stress trend was observed regardless of the glass fiber post treatment. In addition, for the G1 model (without GFP), a high stress magnitude can be noticed with more presence of red and yellow fringes in the proximal faces of enamel and dentin tissue. To quantify the model's comparison, the stress peaks were recorded and are summarized in Tables 2 and 3.

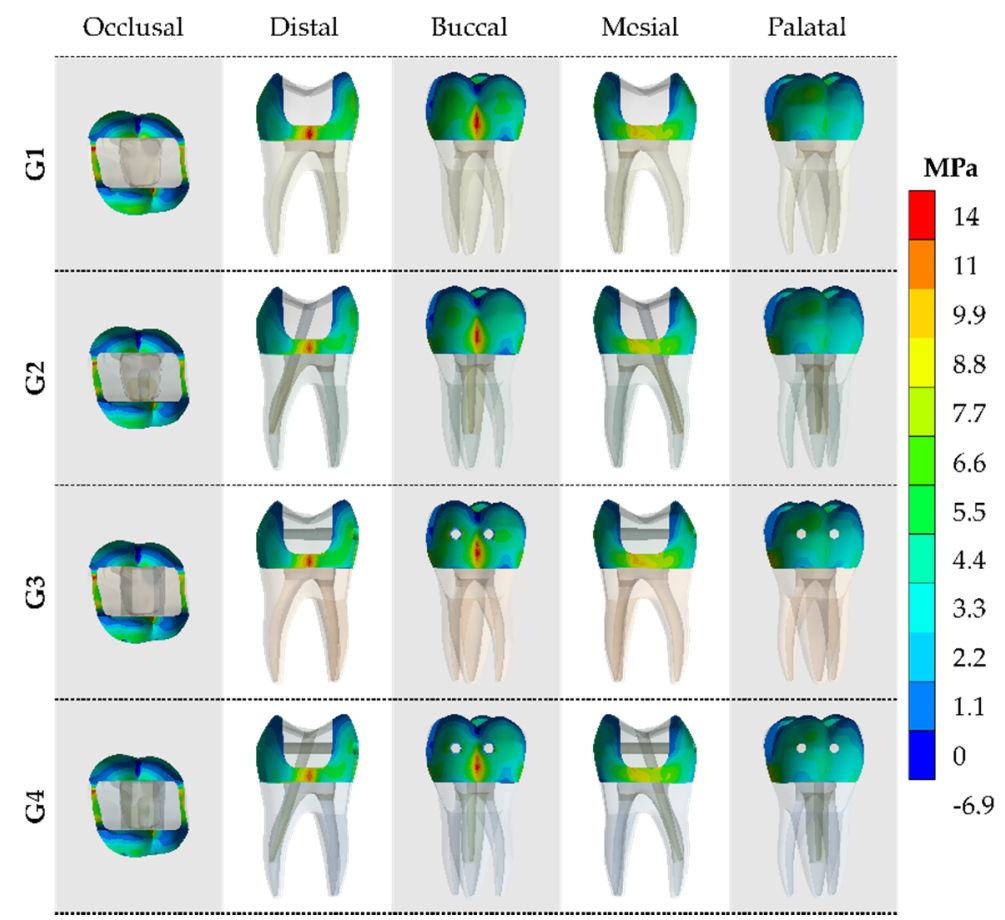

Figure 4. The maximum principal stress $(\mathrm{MPa})$ concentration from five different viewpoints in the enamel tissue according to the GFP treatment. 


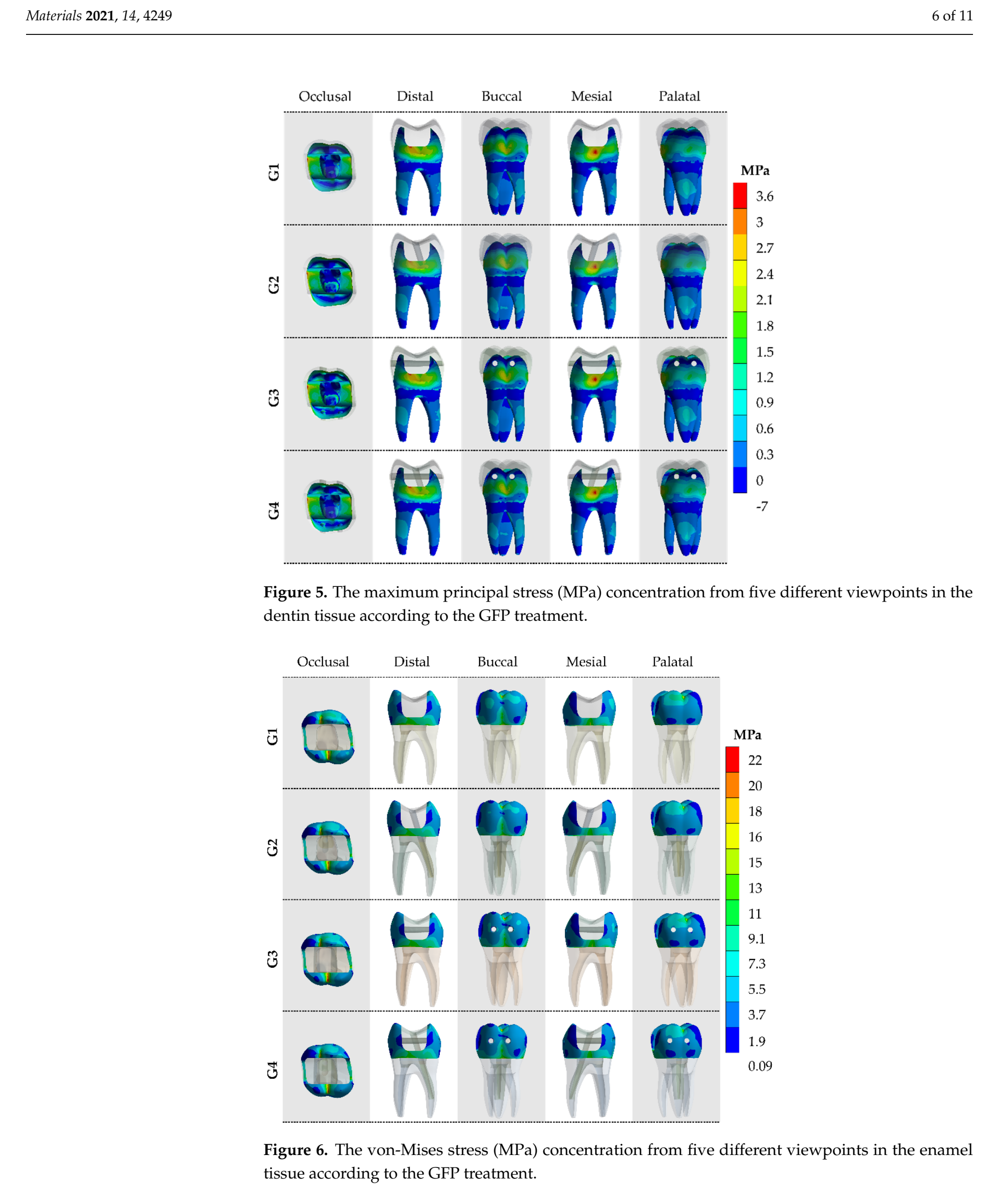




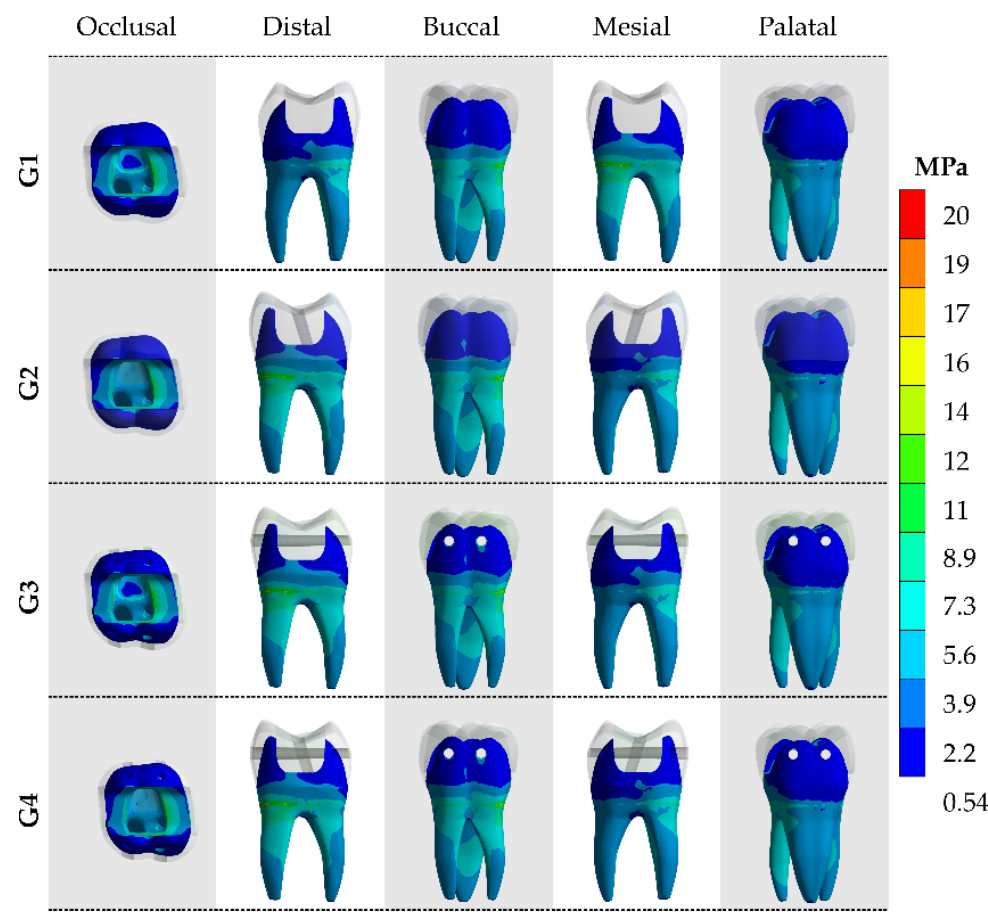

Figure 7. The von-Mises stress (MPa) concentration from five different viewpoints in the dentin tissue according to the GFP treatment.

Table 2. Tensile stress peaks (MPa) obtained in enamel and dentin tissue after the analysis process.

\begin{tabular}{cccc}
\hline Model & Glass Fiber Post Approach & Enamel Stress & Dentin Stress \\
\hline G1 & No-post & 14.5 & 3.7 \\
G2 & Glass fiber in the palatal root canal & 13.9 & 3.2 \\
G3 & Two transfixed glass fiber posts & 14.2 & 3.4 \\
G4 & Two transfixed glass fiber posts and one glass & 14.0 & 3.3 \\
\hline
\end{tabular}

Table 3. Von-Mises stress peaks (MPa) obtained in enamel and dentin tissue after the analysis process.

\begin{tabular}{cccc}
\hline Model & Glass Fiber Post Approach & Enamel Stress & Dentin Stress \\
\hline G1 & No-post & 18.17 & 11.68 \\
G2 & Glass fiber in the palatal root canal & 17.58 & 11.18 \\
G3 & Two transfixed glass fiber posts & 17.87 & 11.38 \\
G4 & Two transfixed glass fiber posts and one glass & 17.68 & 11.28 \\
& fiber post in the palatal root canal. & & \\
\hline
\end{tabular}

\section{Discussion}

First molars are teeth frequently involved in endodontic therapy [27]; therefore, the use of resin composite restorations after endodontic treatments should improve the mechanical resistance against the occlusal loads, as well as the restoration of missing dental tissue. However, this mechanical effect is not a consensus in the literature. The failures in endodontically treated teeth are still widely reported even after restorative procedures.

Previous reports showed that the fracture resistance during in vitro compressive loads could be enhanced with the GFP transfixed placement in posterior teeth $[8,14,30]$. There are reports affirming that the use of two transfixed GFPs in MOD-prepared cavities led to recovery of approximately $23 \%$ more fracture strength than teeth without GFPs [30]. According to the authors, a possible explanation would be the reduction of cusp deflection caused by anchoring of buccal and lingual walls of the cavity. The present study showed 
a slight stress reduction with the use of GFP regardless of the post-endodontic treatment that could be associated with the reduction in cusp's displacements; however, with values lower than $2 \%$ in enamel tissue and $8 \%$ in dentin tissue comparing G1 and G3. Therefore, it is possible to suggest that the GFP effect would be more noticeable when the adhesion is not ideal between resin composite restoration and cavity walls.

The mechanical properties of the restorative materials can determine the clinical performance of restored endodontically treated teeth, especially the elastic modulus of the post system [31]. Rigid posts, such as metallic and zirconia, generates less stress in the cement layer, however, concentrate more on root dentin and, thus, catastrophic root fractures can occur if the tooth is overloaded. On the other hand, less rigid posts, like the fiber-reinforced posts, can deflect under high loads, which can lead to loss of retention, or even post fracture, however, avoiding root fracture [32]. In this regard, the present study is limited to the mechanical behavior with the use of GFP, however different post systems or transfixed reinforcement systems may modify the calculated stress and should be evaluated in further evaluations.

Another in vitro study [33] reported that the transfixed glass fiber post placement could be an alternative treatment modality for the restoration of endodontically treated teeth. According to the authors, this technique did not improve the fracture resistance of endodontically treated teeth with MOD cavities; the present study corroborates this, since the difference in stress magnitude between models is less than $10 \%$. According to the authors, this mechanical behavior can be explained due to the minimal surface area between the GFP and the tooth structure; hence, it does not provide an adequate area for bonding. In addition, the GFP bond strength with resin cement is weaker than the bond strength between the composite restoration and dental tissue. Finally, the presence of holes in the crown might have affected the fracture resistance of teeth. Therefore, the present study suggests that the elastic modulus of GFP is lower than the enamel, and hence would present considerable flexible structure that cannot act as a stress reduction framework in this case.

Cusp deflection mainly occurs along the bucco-lingual axis and usually occurs because most of the chewing forces on posterior teeth are directed laterally [15]. These directional oblique components of the masticatory load can affect the adhesive layer in MOD cavities, being mandatory the use of effective adhesive systems to retain the restorative materials. In addition to that, with the interface property, the enamel tissue can be considered a brittle material, while dentine is more elastic damping the stress effect at the dentin-enamel junction [15].

On the other hand, when associated with the insertion of GFP in the palatal root canal (G2), there is slightly improvement in the absorption of occlusal loads, associated with stress dissipation along its axis [34], resulting in an improvement in the tooth resistance [35]. This effect has been observed in clinical reports [36,37] corroborating with the results found in the present study.

Another finite element study [38] showed that the use of adhesive GFP was neither able to reduce the maximum stresses calculated on the occlusal surface nor to optimize the stress distribution regardless of different vertical post-approach. According to the authors, the placement of high amount of GFP can be deleterious to the remaining tooth structure without improving the mechanical response against chewing loading. The present study corroborates with this indication, since there use of more GFPs (G4) was not beneficial for the present model stress result.

Although in vitro laboratory tests of extracted human teeth are important to obtain useful information about fracture load and the fracture mode, they are generally based on destructive experiments and have limited capacity to investigate the stress-strain relationship in the tooth restoration complex $[38,39]$. Therefore, 3D-FEA is an engineering tool that can be applied to biology, medicine and dentistry and used to investigate the mechanical behavior of complex systems by a mathematical approach and simulation [37]. The numerical simulation consists of modeling a structure as close as possible to the real one, in 
addition to the correct outputs that should be applicable and practical based in the clinical research to define the boundary conditions. However, restorations have other problems, such as microleakage, polymerization shrinkage of resinous materials and postoperative sensitivity, that should be considered. As oral conditions cannot be completely reproduced by in vitro and in silico studies, further evaluations are still necessary to determine the effectiveness and longevity of GFP treatment in class II MOD cavities [40].

In addition, based on what was said before, the FEA presents limitations related to numerical simulation. Initially, the endodontically treated teeth would be subject to different temperature cycles and $\mathrm{pH}$ variation in the oral cavity. In addition, the simulated materials would present some defects that are not simulated in isotropic structures [41]. There are, possible influences of oblique loading, sliding contacts and operator errors that are simplified [42]. Therefore, further in vitro studies should be carried out to complement the present findings, demonstrating transfixed GFP biological behavior, fatigue survival, and bond strength followed by clinical trials.

\section{Conclusions}

Based on this study's limitations, the use of transfixed glass fiber post generated stresses similar to the absence of a post and is not indicated to improve the endodontically treated molar mechanical response, in both enamel and dentin tissue. The conventional glass fiber post placement is the most suitable technique to reduce the stress magnitude during axial loading.

Author Contributions: Conceptualization, A.L.S.B.; M.T.V.G.; G.S.d.A.; R.M.d.M.; and J.P.M.T.; formal analysis, A.L.S.B.; G.S.d.A.; and J.P.M.T.; investigation, A.L.S.B.; M.T.V.G.; G.S.d.A.; R.M.d.M.; K.B.; L.R.S.-C. and J.P.M.T.; data curation, A.L.S.B.; M.T.V.G.; G.S.d.A.; and J.P.M.T.; writing—original draft preparation, A.L.S.B.; M.T.V.G.; G.S.d.A.; and J.P.M.T.; writing—review and editing, A.L.S.B.; G.S.d.A.; R.M.d.M.; K.B.; L.R.S.-C. and J.P.M.T.; supervision, A.L.S.B.; R.M.d.M.; K.B.; L.R.S.-C. and J.P.M.T. All authors have read and agreed to the published version of the manuscript.

Funding: This research received no external funding.

Institutional Review Board Statement: Not applicable.

Informed Consent Statement: Not applicable.

Data Availability Statement: The data presented in this study are available on request from the corresponding author.

Conflicts of Interest: The authors declare no conflict of interest.

\section{References}

1. da Silva, P.B.; Duarte, S.F.; Alcalde, M.P.; Duarte, M.A.H.; Vivan, R.R.; da Rosa, R.A.; Só, M.V.R.; do Nascimento, A.L. Influence of cervical preflaring and root canal preparation on the fracture resistance of endodontically treated teeth. BMC Oral Health 2020, 20, 111. [CrossRef]

2. Fernandes, A.S.; Dessai, G.S. Factors affecting the fracture resistance of post-core reconstructed teeth: A review. Int. J. Prosthodont. 2001, 14, 355-363.

3. Göktürk, H.; Karaarslan, E.Ş.; Tekin, E.; Hologlu, B.; Sarıkaya, I. The effect of the different restorations on fracture resistance of root-filled premolars. BMC Oral Health 2018, 18, 196. [CrossRef]

4. Scotti, N.; Michelotto Tempesta, R.; Pasqualini, D.; Baldi, A.; Vergano, E.A.; Baldissara, P.; Alovisi, M.; Comba, A. 3D Interfacial Gap and Fracture Resistance of Endodontically Treated Premolars Restored with Fiber-reinforced Composites. J. Adhes. Dent. 2020, 22, 215-224. [CrossRef] [PubMed]

5. Thakur, A.; Ramarao, S. A comparative evaluation of fracture resistance of endodontically treated premolar teeth reinforced with different prefabricated and custom-made fiber-reinforced post system with two different post lengths: An in vitro study. J. Conserv. Dent. 2019, 22, 376. [CrossRef]

6. Pierrisnard, L.; Bohin, F.; Renault, P.; Barquins, M. Corono-radicular reconstruction of pulpless teeth: A mechanical study using finite element analysis. J. Prosthet. Dent. 2002, 88, 442-448. [CrossRef]

7. da Rocha, D.M.; Tribst, J.P.M.; Ausiello, P.; Dal Piva, A.M.D.O.; da Rocha, M.C.; Di Nicoló, R.; Borges, A.L.S. Effect of the restorative technique on load-bearing capacity, cusp deflection, and stress distribution of endodontically-treated premolars with MOD restoration. Restor. Dent. Endod. 2019, 44, e33. [CrossRef] [PubMed] 
8. Scotti, N.; Forniglia, A.; Michelotto Tempesta, R.; Comba, A.; Saratti, C.M.; Pasqualini, D.; Alovisi, M.; Berutti, E. Effects of fiber-glass-reinforced composite restorations on fracture resistance and failure mode of endodontically treated molars. J. Dent. 2016, 53, 82-87. [CrossRef] [PubMed]

9. Karzoun, W.; Abdulkarim, A.; Samran, A.; Kern, M. Fracture Strength of Endodontically Treated Maxillary Premolars Supported by a Horizontal Glass Fiber Post: An In Vitro Study. J. Endod. 2015, 41, 907-912. [CrossRef] [PubMed]

10. Kim, S.G.; Kim, S.S.; Levine, J.L.; Piracha, Y.S.; Solomon, C.S. A Novel Approach to Fracture Resistance Using Horizontal Posts after Endodontic Therapy: A Case Report and Review of Literature. J. Endod. 2020, 46, 545-550. [CrossRef] [PubMed]

11. Reeh, E.S.; Ross, G.K. Tooth stiffness with composite veneers: A strain gauge and finite element evaluation. Dent. Mater. 1994, 10, 247-252. [CrossRef]

12. Cobankara, F.K.; Unlu, N.; Cetin, A.R.; Ozkan, H.B. The effect of different restoration techniques on the fracture resistance of endodontically-treated molars. Oper. Dent. 2008, 33, 526-533. [CrossRef] [PubMed]

13. De Carvalho, A.B.G.; de Andrade, G.S.; Tribst, J.P.M.; Grassi, E.D.A.; Ausiello, P.; Saavedra, G.D.S.F.A.; Bressane, A.; de Melo, R.M.; Borges, A.L. Mechanical behavior of different restorative materials and onlay preparation designs in endodontically treated molars. Materials 2021, 14, 1923. [CrossRef] [PubMed]

14. Favero, F.J.; De Melo, T.A.F.; Stona, D.; Mota, E.G.; Spohr, A.M.; Burnett, L.H. Strengthening effect of horizontally placed fiberglass posts in endodontically-treated teeth restored with direct resin composite. Am. J. Dent. 2015, 28, 143-149. [PubMed]

15. Daher, R.; Feilzer, A.J.; Krejci, I. Novel non-invasive reinforcement of MOD cavities on endodontically treated teeth. J. Dent. 2016, 54, 77-85. [CrossRef]

16. Cantó-Navés, O.; Medina-Galvez, R.; Marimon, X.; Ferrer, M.; Figueras-Álvarez, Ó.; Cabratosa-Termes, J. A 3D Finite Element Analysis Model of Single Implant-Supported Prosthesis under Dynamic Impact Loading for Evaluation of Stress in the Crown, Abutment and Cortical Bone Using Different Rehabilitation Materials. Materials 2021, 14, 3519. [CrossRef]

17. Lee, J.-H.; Jang, H.Y.; Lee, S.Y. Finite Element Analysis of Dental Implants with Zirconia Crown Restorations: Conventional Cement-Retained vs. Cementless Screw-Retained. Materials 2021, 14, 2666. [CrossRef]

18. Cicciù, M. Bioengineering Methods of Analysis and Medical Devices: A Current Trends and State of the Art. Materials 2020, 13, 797. [CrossRef]

19. Nabih, S.M.; Ibrahim, N.I.M.; Elmanakhly, A.R. Mechanical and thermal stress analysis of hybrid ceramic and lithium disilicate based ceramic CAD-CAM inlays using 3-D finite element analysis. Braz. Dent. Sci. 2021, 24. [CrossRef]

20. Ausiello, P.; Ciaramella, S.; Garcia-Godoy, F.; Martorelli, M.; Sorrentino, R.; Gloria, A. Stress distribution of bulk-fill resin composite in class II restorations. Am. J. Dent. 2017, 30, 227-232.

21. Martorelli, M.; Ausiello, P. A novel approach for a complete 3D tooth reconstruction using only $3 \mathrm{D}$ crown data. Int. J. Interact. Des. Manuf. 2013, 7, 125-135. [CrossRef]

22. Tribst, J.P.M.; Dal Piva, A.M.D.O.; Borges, A.L.S.; Araújo, R.M.; da Silva, J.M.F.; Bottino, M.A.; Kleverlaan, C.J.; de Jager, N. Effect of different materials and undercut on the removal force and stress distribution in circumferential clasps during direct retainer action in removable partial dentures. Dent. Mater. 2020, 36, 179-186. [CrossRef]

23. Pałka, K.; Bieniaś, J.; Dębski, H.; Niewczas, A. Finite element analysis of thermo-mechanical loaded teeth. Comput. Mater. Sci. 2012, 64, 289-294. [CrossRef]

24. Holmes, D.C.; Diaz-Arnold, A.M.; Leary, J.M. Influence of post dimension on stress distribution in dentin. J. Prosthet. Dent. 1996, 75, 140-147. [CrossRef]

25. Tribst, J.P.M.; Borges, A.L.S.; Silva-Concílio, L.R.; Bottino, M.A.; Özcan, M. Effect of Restorative Material on Mechanical Response of Provisional Endocrowns: A 3D-FEA Study. Materials 2021, 14, 649. [CrossRef] [PubMed]

26. Lanza, A.; Aversa, R.; Rengo, S.; Apicella, D.; Apicella, A. 3D FEA of cemented steel, glass and carbon posts in a maxillary incisor. Dent. Mater. 2005, 21, 709-715. [CrossRef]

27. Skupien, J.A.; Opdam, N.; Winnen, R.; Bronkhorst, E.; Kreulen, C.; Pereira-Cenci, T.; Huysmans, M.-C. A Practice-based Study on the Survival of Restored Endodontically Treated Teeth. J. Endod. 2013, 39, 1335-1340. [CrossRef] [PubMed]

28. Carvalho, R.M.; Santiago, S.L.; Fernandes, C.A.; Suh, B.I.; Pashley, D.H. Effects of prism orientation on tensile strength of enamel. J. Adhes. Dent. 2000, 2, 251-257. [PubMed]

29. Staninec, M.; Marshall, G.W.; Hilton, J.F.; Pashley, D.H.; Gansky, S.A.; Marshall, S.J.; Kinney, J.H. Ultimate tensile strength of dentin: Evidence for a damage mechanics approach to dentin failure. J. Biomed. Mater. Res. 2002, 63, 342-345. [CrossRef]

30. Bromberg, C.R.; Alves, C.B.; Stona, D.; Spohr, A.M.; Rodrigues-Junior, S.A.; Melara, R.; Burnett, L.H. Fracture resistance of endodontically treated molars restored with horizontal fiberglass posts or indirect techniques. J. Am. Dent. Assoc. 2016, 147, 952-958. [CrossRef]

31. De Andrade, G.S.; Tribst, J.P.M.; Orozco, E.I.; Augusto, M.G.; Bottino, M.A.; Borges, A.L.; Anami, L.C.; Saavedra, G.D. Influence of different post-endodontic restorations on the fatigue survival and biomechanical behavior of central incisors. Am. J. Dent. 2020, 33, 227-234. [PubMed]

32. Stricker, E.J.; Göhring, T.N. Influence of different posts and cores on marginal adaptation, fracture resistance, and fracture mode of composite resin crowns on human mandibular premolars. An in vitro study. J. Dent. 2006, 34, 326-335. [CrossRef] [PubMed]

33. Abou-Elnaga, M.Y.; Alkhawas, M.-B.A.M.; Kim, H.-C.; Refai, A.S. Effect of Truss Access and Artificial Truss Restoration on the Fracture Resistance of Endodontically Treated Mandibular First Molars. J. Endod. 2019, 45, 813-817. [CrossRef] [PubMed] 
34. Pantvisai, P.; Messer, H.H. Cuspal deflection in molars in relation to endodontic and restorative procedures. J. Endod. 1995, 21, 57-61. [CrossRef]

35. Mohammadi, N.; Kahnamoii, M.A.; Yeganeh, P.K.; Navimipour, E.J. Effect of Fiber Post and Cusp Coverage on Fracture Resistance of Endodontically Treated Maxillary Premolars Directly Restored with Composite Resin. J. Endod. 2009, 35, 1428-1432. [CrossRef] [PubMed]

36. Mannocci, F.; Qualtrough, A.J.E.; Worthington, H.V.; Watson, T.F.; Pitt Ford, T.R. Randomized clinical comparison of endodontically treated teeth restored with amalgam or with fiber posts and resin composite: Five-year results. Oper. Dent. 2005, 30, 9-15. [PubMed]

37. Scotti, N.; Eruli, C.; Comba, A.; Paolino, D.S.; Alovisi, M.; Pasqualini, D.; Berutti, E. Longevity of class 2 direct restorations in root-filled teeth: A retrospective clinical study. J. Dent. 2015, 43, 499-505. [CrossRef]

38. Zarow, M.; Vadini, M.; Chojnacka-Brozek, A.; Szczeklik, K.; Milewski, G.; Biferi, V.; D'Arcangelo, C.; De Angelis, F. Effect of Fiber Posts on Stress Distribution of Endodontically Treated Upper Premolars: Finite Element Analysis. Nanomaterials 2020, $10,1708$. [CrossRef]

39. Alp, S..; Gulec Alagoz, L.; Ulusoy, N. Effect of Direct and Indirect Materials on Stress Distribution in Class II MOD Restorations: A 3D-Finite Element Analysis Study. BioMed Res. Int. 2020, 2020, 7435054. [CrossRef]

40. Ausiello, P.; Dal Piva, A.M.D.O.; Borges, A.L.S.; Lanzotti, A.; Zamparini, F.; Epifania, E.; Mendes Tribst, J.P. Effect of Shrinking and No Shrinking Dentine and Enamel Replacing Materials in Posterior Restoration: A 3D-FEA Study. Appl. Sci. 2021, 11, 2215. [CrossRef]

41. Matuda, A.G.N.; Silveira, M.P.M.; Andrade, G.S.D.; Piva, A.M.D.O.D.; Tribst, J.P.M.; Borges, A.L.S.; Testarelli, L.; Mosca, G.; Ausiello, P. Computer Aided Design Modelling and Finite Element Analysis of Premolar Proximal Cavities Restored with Resin Composites. Materials 2021, 14, 2366. [CrossRef] [PubMed]

42. Tribst, J.P.M.; Dal Piva, A.M.O.; Borges, A.L.S.; Anami, L.C.; Kleverlaan, C.J.; Bottino, M.A. Survival Probability, Weibull Characteristics, Stress Distribution, and Fractographic Analysis of Polymer-Infiltrated Ceramic Network Restorations Cemented on a Chairside Titanium Base: An In Vitro and In Silico Study. Materials 2020, 13, 1879. [CrossRef] [PubMed] 